\title{
Correlation between compression strength parallel of wood and charcoal of Eucalyptus clones
}

\section{Correlação entre a resistência à compressão paralela da madeira e do carvão vegetal de clones de Eucalyptus.}

\author{
Luciano Junqueira Costa ${ }^{1}$, Laura Vitoria Lopes Lima ${ }^{1}$, Marcos Oliveira de Paula ${ }^{1}$, \\ Angélica de Cássia Oliveira Carneiro ${ }^{1}$, Matheus Fernandes de Carvalho Reis ${ }^{1}$ \\ and Jéssica Dornelas Soares ${ }^{1}$
}

\begin{abstract}
Resumo
A complexidade do ensaio e a ausência de normas técnicas para os testes de compressão dificultam a determinação das propriedades mecânicas do carvão vegetal, que estão diretamente relacionadas à qualidade e utilização. $\mathrm{O}$ objetivo deste trabalho foi avaliar e correlacionar as propriedades mecânicas da madeira e do carvão vegetal de 11 clones de Eucalyptus sp. Discos de madeira com espessura de $5 \mathrm{~cm}$ foram retirados em diferentes posições da altura comercial do tronco. As carbonizações foram realizadas em forno elétrico (mufla) com temperatura final de $450{ }^{\circ} \mathrm{C}$, e taxa de aquecimento de $1,67^{\circ} \mathrm{C} \cdot \mathrm{min}^{-1}$. Para determinação das propriedades mecânicas, realizaram-se ensaios de compressão paralela às fibras da madeira e do carvão vegetal e, teste de tamboramento para determinar a friabilidade do carvão. A resistência a compressão paralela às fibras do carvão vegetal variou de 6,90 a 8,81 MPa, enquanto que a produção máxima de finos foi de $5,63 \%$, e em média a friabilidade do carvão vegetal foi de 4,98\%. Observou-se, alta e positiva correlação entre a resistência a compressão paralela às fibras do carvão vegetal e a produção de finos. Apesar de ser observada correlação entre as propriedades da madeira e do carvão vegetal, as alterações decorrentes do processo de carbonização, as quais a madeira é exposta, dificultam relação entre as características mecânicas.
\end{abstract}

Palavras - chave: Ensaios; propriedades mecânicas; resistência do carvão vegetal; friabilidade; madeira

\begin{abstract}
The complexity of the test and lack of technical standards for compression testing make it difficult to determinate the mechanical properties of charcoal, which are directly related to quality and use. The present study aimed to evaluate and correlate the mechanical properties of wood and charcoal of 11 clones of Eucalyptus sp. Wood discs of $5 \mathrm{~cm}$ thickness were taken from different positions of the commercial height of the stem. The carbonization process was carried out in a furnace with final temperature of $450{ }^{\circ} \mathrm{C}$ and heating rate of $1.67^{\circ} \mathrm{C} \cdot \mathrm{min}^{-1}$. The mechanical properties were determined by compression parallel to grain test, conducted for the wood and charcoal. Additionally, the tumbler test was carried out to determine the friability of the charcoal. Compression strength parallel to the grain of the charcoal ranged from 6.90 to $8.81 \mathrm{MPa}$, whereas the maximum fines production was $5.63 \%$, and the friability of the charcoal was, on average, $4.98 \%$. It was observed a high and positive correlation between compression strength parallel to the grain and the fines production. Despite the correlation between wood and charcoal properties, changes on the carbonization process make it difficult to establish a relationship between the mechanical characteristics.
\end{abstract}

Keywords: Testing; mechanical properties; resistance of charcoal; friability; wood.

\section{INTRODUCTION}

Charcoal is a carbon-rich material, obtained from the thermal decomposition of wood in the absence or controlled presence of oxygen (ANTAL; GRENDI, 2003) that is being used as fuel in several segments, such as industrial, residential (rural and urban) and commercial sectors.

In Brazil, charcoal is mainly used in the siderugical industry as thermo- reducer of iron ore in the production of pig iron, steel and alloys (BAILIS et al., 2013). The thermo-reducer participation in Brazilian steel sector accounts for nearly $25 \%$ of the pig iron produced (CGEE, 2015). 
Physical, chemical, anatomic and mechanical properties of the charcoal are affected by the properties of the wood, carbonization parameters (temperature and heating rate), and production systems (COUTO et al., 2015).

Mechanical strength stands out among the properties of charcoal that directly affect its performance in the blast furnace, since charcoal is a friable material (LANCELOTTI et al., 2010). Resistance to breakage is essential because charcoal must be able to support the ore load by maintaining the constant permeability of the gas flow necessary for the iron ore reduction process, besides ensuring the performance and structural integrity of the blast furnace (ASSIS et al., 2016).

Friability is defined as the ability of charcoal to generate particles and fines when subjected to abrasion, compression or cracking (SILVA et al., 2007). During handling, charcoal suffers impacts that cause fragmentation and the production of large amounts of fines. Most of these particles are not used by the industry (MARTINS et al., 2016). The generation of charcoal fines during handling, from its production up to its entry into the blast furnace, is approximately $25 \%$. These fines may increase depending on the techniques used during its transportation, storage, loading and unloading, which considerably reduces the final gravimetric yield (ROUSSET et al., 2011). In addition, the high production of fines inside the blast furnace can affect the permeability of the load and damage the interior of the blast furnace due to their abrasive activity, which results in temperature gradients during the reduction process. The low mechanical strength of charcoal, compared to coal, is one of the main hindrances to its use in the steel industry. It also limits the height of the blast furnace (ASSIS et al., 2016).

There are several standardized methods in the literature to determine the physical, chemical and anatomical properties of charcoal. However, there is only one specific standard for mechanical test NBR 8740 (ABNT, 1985), to evaluate the mechanical resistance, the Brazilian Association of Technical Standards (ABNT). It measures the resistance of charcoal to degradation by impact and abrasion. There is no technical standard for performing the test to determine the compression strength parallel or perpendicular to the grain, which makes it difficult to standardize the test. The lack of a specific standard to evaluate resistance to compression has led several authors (COUTO et al., 2015; LANCELOTTI et al., 2010; MOUTINHO et al., 2016) to propose test methodologies. The study on the correlation levels of the mechanical properties between wood and charcoal is relevant, since it allows for the estimate of the value of charcoal resistance based on the mechanical properties of the wood.

Therefore, this study aimed to evaluate the mechanical resistance of charcoal by the compression methods parallel to the grain and the tumbler test. We also attempted to further correlate the physical and mechanical properties of the wood with the characteristics of the charcoal produced in the laboratory.

\section{MATERIAL AND METHODS}

Eleven clones of Eucalyptus sp. from a plantation were used. The plantings were conducted with spacing of $3.0 \times 3.0$ meters, and the trees were harvested at the age of 6.3 years. The plantation belonged to a forestry company, named Votorantim Siderurgia S.A, located in Vazante, Minas Gerais, Brazil.

It was used one tree from each clone and five 5-com thick wood discs were taken from the positions of $0,25,50,75$ and $100 \%$ of the commercial height. A composite sampling was performed and the discs were processed to specimens (tangential, radial and transverse directions) with $2 \times 2 \times 3 \mathrm{~cm}$, and 10 specimens were used for each subsequent analysis. In order to avoid the influence of the radial sampling position on the mechanical properties of both the wood and the resulting charcoal, it was selected only the wood specimens from the intermediate region of the discs free from knots, holes or any other defect that could affect the mechanical resistance values obtained during the tests.

After obtaining the wood specimens, they were conducted to determine the basic density, through the method of immersion in water, according to the NBR 11941 standard (ABNT, 2003).

Compression strength parallel to the grain of the wood was carried out using load cell of 5 tons and speed of load application of $5.00 \mathrm{~mm}$. $\mathrm{min}^{-1}$. The specimens at the time of testing showed $12 \%$ of moisture content.

The carbonization system consisted of a furnace, a cylindric carbonization reactor, a water-cooled condenser and a container for collecting the condensable gas. The heating control was conducted manually in increments of $50^{\circ} \mathrm{C}$ every 30 minutes, corresponding to an average heating rate of $1.67^{\circ} \mathrm{C}$.

Sci. For., Piracicaba, v. 46, n. 120, p. 606-613, dez. 2018

DOI: dx.doi.org/10.18671/scifor.v46n120.09 
$\min ^{-1}$. The initial temperature was $100{ }^{\circ} \mathrm{C}$ and the final temperature was $450{ }^{\circ} \mathrm{C}$. The maximum temperature exposure time was 30 minutes for all evaluated materials.

The charcoal test specimens were manufactured with dimensions of $1.8 \times 1.8 \times 2.5 \mathrm{~cm}$ (tangential, radial and transverse direction) for mechanical compression tests parallel to the grain. Wood sanding was used to remove the deformations resulted from the carbonization and adjust the dimensions.

The bulk density of the charcoal was determined by the hydrostatic method, in which the samples were immersed in mercury, as described by Vital (1984). The charcoal samples have presented a moisture content of around 5\% on dry basis at the time of the testing.

A 1 ton load cell was used for the compression strength parallel to the grain of the charcoal. The speed of application of the load was set at $0.2 \mathrm{~mm}$. $\mathrm{min}^{-1}$ and the breakpoint was established at $20 \%$ loss of the material resistance. It indicated the rupture of the sample and the destruction of its structural arrangement and ended the test (MOUTINHO et al., 2016).

Compression strength parallel to the grain for both wood and charcoal was carried out in a universal test machine, Contenco UMC (10T) model, with load capacity of $100 \mathrm{kN}$.

To perform the tumbler test, $20 \mathrm{~g}$ of charcoal were inserted in a rotating drum with rotation of $31 \mathrm{rpm}$ for 17 minutes, according to the CETEC procedure (CETEC, 1982), with adaptations on the process to reduce the amount of charcoal on the equipment, from $500 \mathrm{~g}$ to $20 \mathrm{~g}$. An MA $791-$ Marconi friabilimiter was used to perform the test. At the end of the test, the mass loss from the specimens was separated with the use of a $9.5 \mathrm{~mm}$ sieve, and the friability was calculated.

The data were subjected to the analysis of variance. When significant differences were established, treatments were compared through the Scott-Knott test, at 5\% probability. Pearson's correlation coefficient was used with $5 \%$ probability to determine the correlation between the physical and mechanical properties of wood and charcoal.

The statistical analyses were conducted using the R statistical software version 3.3.2.

\section{RESULTS AND DISCUSSIONS}

Table 1 shows the mean values of compression parallel to the grain for charcoal and wood, proportion of fines in the tumbler test, bulk density of charcoal, wood basic density for the 11 clones. The multiple comparison test performed is also presented.

Table 1 shows that, except for basic wood density, there was significant effect of clone for the other properties studied.

The compression strength parallel to the grain of the charcoal was on average about $80 \%$ less than the average value observed for compression strength parallel to wood grain. The low mechanical resistance values observed for charcoal in relation to wood are related to the loss of mass, changes in

Table 1. Means values of physical and mechanical properties of charcoal

Tabela 1. Valores médios e teste de média para as propriedades físicas e mecânicas do carvão vegetal

\begin{tabular}{cccccc}
\hline Clone & BD $\left(\mathbf{g} \cdot \mathbf{c m}^{-3}\right)$ & $\sigma_{\mathbf{w}}(\mathbf{M P a})$ & $\mathbf{B D C}\left(\mathbf{g} \cdot \mathbf{c m}^{-3}\right)$ & $\sigma_{\mathrm{c}}(\mathbf{M P a})$ & Fines (\%) \\
\hline 1 & $0.564 \mathrm{a}$ & $41.73 \mathrm{~b}$ & $0.321 \mathrm{~b}$ & $7.18 \mathrm{~b}$ & $4.17 \mathrm{~b}$ \\
2 & $0.546 \mathrm{a}$ & $48.00 \mathrm{a}$ & $0.347 \mathrm{a}$ & $7.86 \mathrm{~b}$ & $4.91 \mathrm{a}$ \\
3 & $0.548 \mathrm{a}$ & $48.51 \mathrm{a}$ & $0.350 \mathrm{a}$ & $6.90 \mathrm{~b}$ & $4.17 \mathrm{~b}$ \\
4 & $0.508 \mathrm{a}$ & $38.79 \mathrm{~d}$ & $0.295 \mathrm{~b}$ & $8.55 \mathrm{a}$ & $5.25 \mathrm{a}$ \\
5 & $0.521 \mathrm{a}$ & $40.65 \mathrm{c}$ & $0.309 \mathrm{~b}$ & $8.38 \mathrm{a}$ & $5.63 \mathrm{a}$ \\
6 & $0.516 \mathrm{a}$ & $43.02 \mathrm{~b}$ & $0.289 \mathrm{~b}$ & $8.76 \mathrm{a}$ & $5.55 \mathrm{a}$ \\
7 & $0.491 \mathrm{a}$ & $33.24 \mathrm{e}$ & $0.381 \mathrm{a}$ & $8.49 \mathrm{a}$ & $5.37 \mathrm{a}$ \\
8 & $0.500 \mathrm{a}$ & $37.87 \mathrm{~d}$ & $0.287 \mathrm{~b}$ & $8.81 \mathrm{a}$ & $5.46 \mathrm{a}$ \\
9 & $0.484 \mathrm{a}$ & $39.41 \mathrm{c}$ & $0.317 \mathrm{~b}$ & $7.81 \mathrm{~b}$ & $4.51 \mathrm{~b}$ \\
10 & $0.532 \mathrm{a}$ & $32.19 \mathrm{e}$ & $0.298 \mathrm{~b}$ & $8.69 \mathrm{a}$ & $5.16 \mathrm{a}$ \\
11 & $0.506 \mathrm{a}$ & $37.55 \mathrm{~d}$ & $0.303 \mathrm{~b}$ & $8.23 \mathrm{a}$ & $4.65 \mathrm{~b}$ \\
Mean & 0.520 & 40.08 & 0.318 & 8.15 & 4.98 \\
VC (\%) & 7.55 & 12.67 & 11.41 & 9.71 & 11.47
\end{tabular}

$\sigma_{c}$ : Compression strength parallel to the grain of the charcoal, in MPa; $\sigma_{w}::$ Compression strength parallel to the grain of wood, in MPa; BDC: Bulk density of charcoal, in $\mathrm{g} . \mathrm{cm}^{-3}$; BD: Basic density of wood, in $\mathrm{g} . \mathrm{cm}^{-3}$. Means in column followed by same letter do not differ at $5 \%$ probability by Scott-Knott test. 
its physical and chemical structure related to thermal degradation of wood constituents and release of volatile gases with increased intensity, up to $500{ }^{\circ} \mathrm{C}$ (ASSIS et al., 2016; COUTO et al., 2015; SHOULAIFAR et al., 2014).

Kocaefe et al. (2008) and Silva et al. (2015) observed that the mechanical properties were affected by the action of temperatures up to $230^{\circ} \mathrm{C}$, /the hemicelluloses degradation was mostly responsible and a minor effect by the ramification of lignin and crystallization of cellulose. Cellulose is the major chemical constituent of wood and accounts for 40 to $45 \%$ of the dry matter of most wood. It is a linear homopolymer composed of D-glucopyranose units linked by $\beta$-1,4-glycosidic bonds (ROWELL et al., 2005). In the carbonization process, cellulose is degraded at temperatures between 260 and $370{ }^{\circ} \mathrm{C}$ (PEREIRA et al., 2013). Above $370{ }^{\circ} \mathrm{C}$, cellulose is almost completely decomposed in a short time.

According to Yang et al. (2007), the thermal degradation range of lignin occurs slowly from 100 to $900{ }^{\circ} \mathrm{C}$. Above $500{ }^{\circ} \mathrm{C}$, the mass loss occurs without great variation in its behavior. The thermal degradation of cellulose and lignin during wood carbonization is the main factor leading to the low mechanical strength of the charcoal to compression (ASSIS et al., 2016; COUTO et al., 2015; PEREIRA et al., 2013).

The charcoal obtained from the evaluated species generally presented low generation of fines, which indicates low friability. According to Silva et al. (2014), this property is important for charcoal because it indicates that the material can be handled without great losses due to the breaking of the charcoal and, consequently, the production of particles or fines. When the quantity of fines generated is less than $10 \%$, charcoal is classified as low friable (SILVA et al., 2007).

The values of compression strength parallel to the grain of the charcoal observed for the clones ranged from 6.90 to $8.81 \mathrm{MPa}$. Moutinho et al. (2017) studied the mechanical behavior of charcoal from 8 species of Eucalyptus sp. and observed resistance values between 7.32 and $13.62 \mathrm{MPa}$. Assis (2016) investigated the mechanical behavior of charcoal from a hybrid clone of Eucalyptus urophylla carbonized at temperatures of $500{ }^{\circ} \mathrm{C}$ and $900{ }^{\circ} \mathrm{C}$ and found mean values for resistance of $1.5 \mathrm{MPa}$ and $3.8 \mathrm{MPa}$, respectively, which are lower than the means found in this study. The differences observed in the studies concerning the values of mechanical resistance are related to the heating rate, final carbonization temperature, methodologies for the preparation of test specimens and parameters adopted during the tests.

Although significant differences in basic wood density were not observed among the clones, the values obtained ranged from 0.484 to $0.564 \mathrm{~g} . \mathrm{cm}^{-3}$. The value of the basic wood density was on average around $42 \%$ higher than the average value of the charcoal bulk density, which demonstrates the changes in physical properties resulting from the transformation of wood into charcoal. According to Santos et al. (2011), high values of basic wood density are interesting for charcoal production, since approximately $60 \%$ of its mass is volatilized due to the thermal degradation of the wood. Moreover, the higher the wood basic density, the higher the carbonization yield, which can provide charcoal with better mechanical properties.

Table 2 shows coefficients of linear correlation between the physical and mechanical properties of wood and charcoal from the clones evaluated in the study.

Table 2 shows that the coefficients were significant only for the correlations between: the compression strength of the charcoal and the proportion of fines; the resistance of the charcoal and the compression strength of the wood; the compression strength of the charcoal and the basic density; and between the friability of the charcoal and wood resistance. It is important to highlight that the compression strength of the charcoal has high and positive correlation with the proportion of fines generated.

Table 2. Correlation between wood and charcoal properties

Tabela 2. Correlação entre propriedades da madeira e do carvão vegetal

\begin{tabular}{cccccc}
\hline Parameters & $\mathrm{BD}\left(\mathbf{g} \cdot \mathbf{c m}^{-3}\right)$ & $\sigma_{\mathrm{w}}(\mathrm{MPa})$ & $\mathrm{BDC}\left(\mathbf{g} \cdot \mathrm{cm}^{-3}\right)$ & $\sigma_{\mathrm{c}}(\mathrm{MPa})$ & Fines $(\%)$ \\
\hline $\mathrm{BD}\left(\mathrm{g} \cdot \mathrm{cm}^{-3}\right)$ & 1 & $0.2806^{\mathrm{ns}}$ & $0.0056^{\mathrm{ns}}$ & $-0.4903^{*}$ & $-0.1715^{\mathrm{ns}}$ \\
$\sigma_{\mathrm{w}}(\mathrm{MPa})$ & & 1 & $0.1284^{\mathrm{ns}}$ & $-0.4146^{*}$ & $-0.3520^{*}$ \\
$\mathrm{BDC}\left(\mathrm{g} \cdot \mathrm{cm}^{-3}\right)$ & & 1 & $-0.3101^{\mathrm{ns}}$ & $-0.2263^{\mathrm{ns}}$ \\
$\sigma_{\mathrm{c}}(\mathrm{MPa})$ & & & 1 & $0.6804^{*}$ \\
Fines $(\%)$ & & & & 1 \\
\hline
\end{tabular}

BD: Basic density of wood; $\sigma_{w}$ : Compression strength parallel to the grain of wood; BDC: Bulk density of charcoal; $\sigma_{c}$ : Compression strength parallel to the grain of charcoal; * and ns: significant and non- significant effect, respectively, at $5 \%$ probability. 
Figure 1 shows the equations that best described the behavior of variables presenting significant correlation with each other.

Low coefficients of determination were found for the models correlating charcoal mechanical resistance with wood compression strength the generation of fines with wood compression strength and mechanical resistance to the compression of the charcoal with wood basic density. On the other hand, the estimation model of charcoal mechanical resistance with the generation of fines presented high coefficient of determination.

During carbonization, increased temperature causes significant modifications in the physical, chemical and anatomical structure of the wood, due to the thermal degradation of its constituents, which provides charcoal with different properties, depending on the final temperature of carbonization (ZHAO et al., 2013). Increased temperature leads to carbon concentration in the material, due to the volatilization of organic matter, primarily because of oxygen release (PEREIRA et al. 2013). According to Somerville and Jahanshahi (2015), materials bearing high levels of carbon have the ability to form bonds between them. Their different combinations may result in materials with diverse characteristics, depending on the parameters of production and the raw materials employed. The structural reorganization of carbon atoms during carbonization leads to the formation of structures similar to graphitic crosslinked among them, in which increases mechanical resistance, due to the increased number of bonds between the carbon chains (COUTO et al., 2015; HAN et al., 2014). However, the increased number of carbon bonds can result in a less ductile material, more fragile to impacts, besides increased production of fines in species with greater resistance to compression.

It was also observed the occurrence of a negative and significant correlation between the compression strength parallel to the grain applied to charcoal and to wood. According to Pereira et al. (2016), the changes occurring in the anatomical structure recurrent from the transformation of wood into charcoal
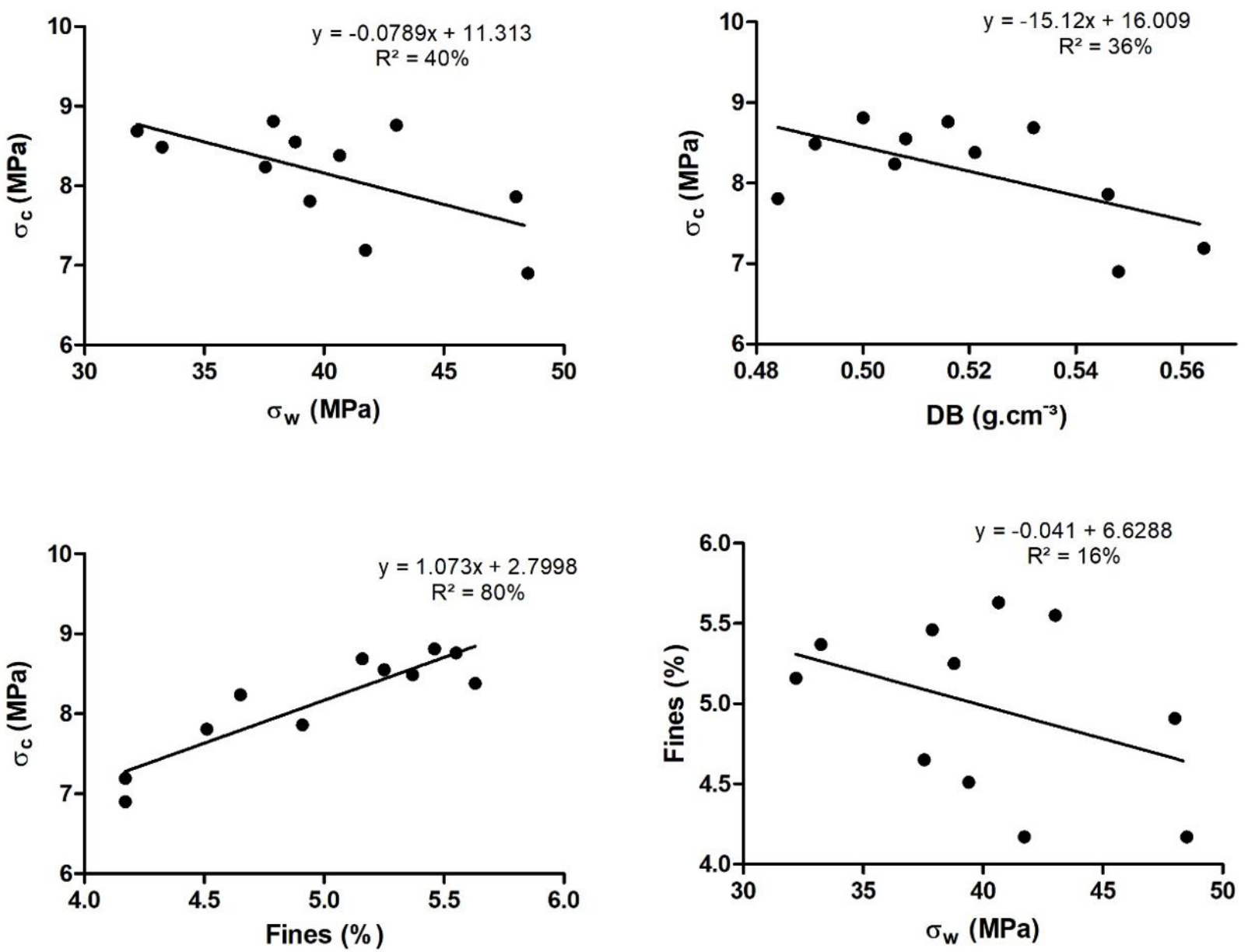

Figure 1. Means values observed and estimated by the equations that best explained the correlations between the dependent and independent variables.

Figura 1. Valores médios observados e estimados pelas equações que melhor explicaram as correlações existentes entre as variáveis dependentes e independentes. 
are related to changes in the quantitative parameters, such as the thickness of the walls of the fibers and diameters of the pores. Besides, fibers are the cells most affected by the carbonization process. Reduced thickness of cell wall clearly results from the thermal degradation of wood constituents. In addition, after pyrolysis, the fibers become glassy and brittle. The frequency and diameter of the pores in the charcoal are significantly different, compared to the originated wood. The contractions that occur during the carbonization process lead to reduced dimensions and increased frequency of pores per $\mathrm{mm}^{2}$. Despite the reduced pore dimensions in the charcoal compared to wood, the high frequency of pores per $\mathrm{mm}^{2}$ contributes to charcoal high porosity, which is on average $75 \%$ higher than that observed in wood (OLIVEIRA et al., 2010). Anatomical modifications associated with changes in chemical composition, structural rearrangement and mass loss due to thermal degradation hinder the establishment of correlations between the mechanical properties of wood and the properties of charcoal.

\section{CONCLUSIONS}

Regarding the evaluated genetic materials, the compression strength parallel to the grain of the charcoal has a high and positive correlation with the proportion of fines generated.The greater the resistance of the charcoal to the compression parallel to the grain, the greater its friability. In this study, no correlation was observed between apparent relative density and friability of charcoal.

The tumbler test resulted in low charcoal friability since the quantity of fines generated was less than $10 \%$.This property is important because it indicates that the material can be handled without great losses.

It was observed a negative and significant correlation between the compression strength parallel to the grain of the charcoal and the generation of fines with the compression strength parallel to the wood fibers. The physical, chemical and anatomical changes that wood undergoes during the carbonization process make it difficult to establish a correlation between its physical and mechanical properties and the properties of the resulting charcoal.

\section{REFERENCES}

ANTAL, M. J.; GRENDI, M. The art, science, and technology of charcoal production. Industrial \& Engineering Chemistry Research, Washington, v. 42, n. 8, p. 1619-1640, 2003.

ABNT - ASSOCIAÇÃO BRASILEIRA DE NORMAS TÉCNICAS - ABNT. NBR 11941. Wood: Determination of Basic Density. Rio de Janeiro, 2003. 6 p.

ABNT - ASSOCIAÇÃO BRASILEIRA DE NORMAS TÉCNICAS - ABNT. NBR 8740. Determination of Breakage and Abrasion. Rio de Janeiro, 1985. 4 p.

ASSIS, M. R.; BRANCHERIAU, L.; NAPOLI, A.; TRUGILHO, P. F. Factors affecting the mechanics of carbonized wood: literature review. Wood Science and Technology, New York, v. 1, n. 3, p. 1-18, 2016.

BAILIS, R.; RUJANAVECH, C.; DWIVEDI, P.; VILELA, A. O.; CHANG, H.; MIRANDA, R. C. Innovation in charcoal production: A comparative life-cycle assessment of two kiln technologies in Brazil. Energy for Sustainable Development, Portland, v. 17, n. 2, p. 189-200, 2013.

CGEE - CENTRO DE GESTÃO E ESTUDOS ESTRATÉGICOS. Modernization of Charcoal Production in Brazil: Review of Subsidies to Steel Plan. Brasília: CGEE, 2015. 150 p.

COUTO, A. M.; TRUGILHO, P. F.; NAPOLI, A.; LIMA, J. T.; SILVA, J. R. M.; PROTÁSIO, T. P. Quality of charcoal from Corymbia and Eucalyptus produced at different final carbonization temperatures. Scientia Forestalis, Piracicaba, v. 43, n. 108, p. 817-831, 2015.

CETEC - FUnDAÇÃO CENTRO TECNOLÓGICO DE MINAS GERAIS. Production and Use of Charcoal. Belo Horizonte: CETEC, 1982. 393 p.

HAN, S. W.; JUNG, D. W.; JEONG, J. H.; OH, E. S. Effect of pyrolysis temperature on carbon obtained from green tea biomass for superior lithium ion battery anodes. Chemical Engineering Journal, Lausanne, v. 254, n. 20, p. 597-604, 2014. 
Costa et al. - Correlation between compression strength parallel of wood and

charcoal of Eucalyptus clones

KOCAEFE, D.; PONCSAK, S.; BOLUK, Y. Effect of thermal treatment on the mechanical composition and mechanical properties of Birch and Aspen. BioResources Technology, Raleigh, v. 3, n. 2, p. 517-537, 2008.

LANCELOTTI, C.; MADELLA, M.; AJITHPRASAD, P.; PETRIE, C. A. Temperature, compression and fragmentation: an experimental analysis to assess the impact of taphonomic processes on charcoal preservation. Archaeology Anthropology Science, Heidelberg, v. 2, n. 4, p. 307-320, 2010.

MARTINS, M. P.; BENÍCIO, E. L.; DIAS JÚNIOR, A. F.; ALMEIDA, R. B.; CARVALHO, A. M.; YAMAJI, F. M. Production and evaluation of charcoal fines briquettes compressed with cellulosic waste from paper and pulp industry. Revista Árvore, Viçosa, v. 40, n. 1, p. 173-180, 2016.

MOUTINHO, V. H. P.; TOMAZELLO FILHO, M.; BRITO, J. O.; BALLARIN, A. W.; ANDRADE, F. W. C.; CARDOSO, C. C. Characterization and statistical correlation between charcoal's physical and mechanical properties of Eucalyptus and Corymbia clones. Ciência Florestal, Santa Maria, v. 27, n. 3, p. 1095-1103, 2017.

MOUTINHO, V. H. P.; TOMAZELLO FILHO, M.; BRITO, J. O.; BALLARI, A. W.; ANDRADE, F. W. C. Influence of the wood physical properties on the charcoal physical and mechanical properties. Scientia Forestalis, Piracicaba, v. 44, n. 111, p. 557-561, 2016.

OLIVEIRA, A. C.; CARNEIRO, A. C. O.; VITAL, B. R.; ALMEIDA, W.; PEREIRA, B. L. C.; CARDOSO, M. T. Quality parameters of Eucalyptus pellita F. Muell. Wood and charcoal. Scientia Forestalis, Piracicaba, v. 38, n. 87, p. 431-439, 2010.

PEREIRA, B. L. C.; CARVALHO, A. M. M. L.; OlIVEIRA, A. C.; SANTOS, L. C.; CARNEIRO, A. C. O.; MAGALHÃES, M. A. Effect of wood carbonization in the anatomical structure and density of charcoal from Eucalyptus. Ciência Florestal, Santa Maria, v. 26, n. 2, p. 545-557, 2016.

PEREIRA, B. L. C.; CARNEIRO, A. C. O.; CARVALHO, A. M. M. L.; TRUGILHO, P. F.; MELO, I. C. N. A.; OLIVEIRA, A. C. Study of thermal degradation of eucalyptus wood by thermogravimetry and calorimetry. Revista Árvore, Viçosa, v. 37, n. 3, p. 567-576, 2013.

ROUSSET, P.; PIRES, A. C.; SABLOWSKI, A.; RODRIGUES, T. LCA of Eucalyptus wood charcoal briquettes. Journal of Cleaner Production, Amsterdam, v. 19, n. 14, p. 1647-1653, 2011.

ROWELL, R. M.; PETTERSEN, R.; HAN, J. S.; ROWELL, J. S.; TSHABALALA, M. A.et al. Cell wall chemistry. In: ROWELL, R. M. (Ed.). Handbook of wood chemistry and wood composites. Boca Raton: CRC Press, 2005. p. $121-138$.

SANTOS, R. C.; CARNEIRO, A. C. O.; CASTRO, A. F. M.; CASTRO, R. V. O.; BIANCHE, J. J.; SOUZA, M. M.; CARDOSO, M. T. Correlation of quality parameters of wood and charcoal of clones of Eucalyptus. Scientia Forestalis, Piracicaba, v. 39, n. 90, p. 221-230, 2011.

SHOULAIFAR, T. K.; DEMARTINI, N.; WILLFOR, S.; PRANOVICH, A.; SMEDS, A. I.; VIRTANEN, T. A. P.; MAUNU, S. L.; VERHOEFF, F.; JACOP, H. A.; KIEL, J. H. A.; HUPA, M. Impact of Torrefaction on the Chemical Structure of Birch Wood. Energy Fuels, Washington, v. 28, n. 6, p. 3863-3872, 2014.

SILVA, M. R.; BRITO, J. O.; GOVONE, J. S.; MACHADO, G. O.; CALIL JUNIOR, C.; CHRISTOFORO, A. L.; LAHR, F. A .R. Chemical and Mechanical Properties Changes in Corymbia Citriodora Wood Submitted to Heat Treatment. International Journal of Materials Engineering, Rosemead, v. 5, n. 4, p. 98-104, 2015.

SILVA, D. A.; ALMEIDA, V. C.; VIANA, L. C.; KLOCK, U.; MUÑIZ, G. I. B. Evaluation of the energy-related properties of tropical wood waste using NIR spectroscopy. Floresta e Ambiente, Seropédica, v. 21, n. 4, p. 561-568, 2014.

SILVA, M. G.; NUMAZAWA, S.; ARAUJO, M. M.; NAGAISHI, T. Y. R.; GALVÃO, G. R. Charcoal from timber industry residues of three tree species logged in the municipality of Paragominas, PA. Acta Amazônica, Manaus, v. 37, n.1, p. 61-70, 2007.

SOMERVILLE, M.; JAHANSHAHI, S. The effect of temperature and compression during pyrolysis on the density of charcoal made from Australian eucalypt wood. Renewable Energy, kidlington, v. 80, n. 8, p. 471-78, 2015.

VITAL, B. R. Methods for Determining Wood Density. Viçosa: Society for Forest Research, 1984.21 p. (Boletim técnico, 1). 
YANG, H.; YAN, R.; CHEN, H.; LEE, D. H.; ZHENG, C. Characteristics of hemicellulose, cellulose and lignin pyrolysis. Fuel, London, v. 86, p. 1781-1788, 2007.

ZHAO, L.; CAO, X.; MASEK, O.; ZIMMERMAN, A. Heterogeneity of biochar properties as a function of feedstock sources. Journal of Hazardous Materials, Amsterdam, v. 257, p. 1-9, 2013.

Recebido em: 2017/10/10

Aceito em: 2018/05/09 